Contribution from the Institut für Anorganische Chemie, Universität Regensburg, Universitätsstrasse 31, D-8400 Regensburg, FRG

\title{
Photochemistry of Tetrasulfido Complexes of Molybdenum(VI), Tungsten(VI), Vanadium(V), and Rhenium(VII)
}

\author{
A. Vogler* and H. Kunkely \\ Received July 8, 1987 \\ The tetrasulfido complexes $\left[\mathrm{MoS}_{4}\right]^{2-},\left[\mathrm{WS}_{4}\right]^{2-},\left[\mathrm{VS}_{4}\right]^{3-}$, and $\left[\mathrm{ReS}_{4}\right]^{-}$photolyze in solution in the presence of air according to the \\ stoichiometry $\left[\mathrm{MS}_{4}\right]^{n-}+\mathrm{O}_{2} \rightarrow\left[\mathrm{MO}_{2} \mathrm{~S}_{2}\right]^{n}+\mathrm{S}_{2}$. The diatomic sulfur can be scavenged by norbornadiene or tetramerizes to yield \\ stable $S_{8}$. Quantum yields are strongly wavelength-dependent. For all complexes the reactive excited states are of the ligand to \\ metal charge transfer type.
}

\section{Introduction}

Sulfido complexes of transition metals, particularly those of molybdenum, have been investigated extensively during recent years. ${ }^{1,2}$ This interest is related to the importance of these compounds in biological redox processes ${ }^{3-6}$ and industrial applications such as the hydrodesulfurization reaction. ${ }^{7-9}$

Transition-metal sulfur compounds are also involved in some remarkable photochemical reactions. As semiconductors, metal sulfides participate in light-induced reactions of organic and inorganic substrates. ${ }^{10-12}$ Metallosulfur proteins are active in the photosynthesis ${ }^{13}$ and sulfur metabolism of phototropic bacteria. ${ }^{14}$ Despite these observations, not much is known about the light sensitivity of simple transition-metal complexes containing sulfur coordinating ligands. While some studies on complexes with more complicated sulfur ligands were reported, ${ }^{15-23}$ the photochemical behavior of simple thiometalates is virtually unknown. This lack is quite surprising since the electronic spectra of complexes such as $\left[\mathrm{MoS}_{4}\right]^{2-}$ are fairly well understood. ${ }^{1,24}$ In addition, even some information on the structures of electronically excited states of $\left[\mathrm{MoS}_{4}\right]^{2-}$ and $\left[\mathrm{WS}_{4}\right]^{2-}$ is available. ${ }^{25,26}$ Finally, the photochem-

(1) Müller, A.; Diemann, E.; Jostes, R.; Bögge, H. Angew. Chem., Int. Ed. Engl. 1981, 20,934.

(2) Wedd, A. G. In Sulfur; Müller, A., Krebs, B., Eds.; Studies in Inorganic Chemistry 5; Elsevier: Amsterdam, 1984; p 181.

(3) Coughlan, M. P., Ed. Molybdenum and Molybdenum-Containing Enzymes; Pergamon: Oxford, U.K., 1980.

(4) Averill, B. Struct. Bonding (Berlin) 1983, 53, 59

(5) Burgmayer, S. J. N.; Stiefel, E. I. J. Chem. Ed. 1985, 62, 943.

(6) Newton, W. E. In Sulfur; Müller, A., Krebs, B., Eds.; Studies in Inorganic Chemistry 5; Elsevier: Amsterdam, 1984; p 409.

(7) Massoth, F. E. Adv. Catal. 1978, 27, 265.

(8) Gates, B. C.; Katzer, J. R.; Schuit, G. C. A. Chemistry of Catalytic Processes; McGraw-Hill: New York, 1979; $\mathrm{p} 390$.

(9) Kwart, H.; Schmit, G. C. A.; Gates, B. C. J. Catal. 1980, 61, 128.

(10) Zeug, N.; Bücheler, J.; Kisch, H. J. Am. Chem. Soc. 1985, 107, 1459.

(11) (a) Borgarello, E.; Serpone, N.; Grätzel, M.; Pelizzetti, E. Inorg. Chim. Acta 1986, 112, 197. (b) Borgarello, E.; Terzian, R.; Serpone, N.; Pelizzetti, E.; Barbeni, M. Inorg. Chem. 1986, 25, 2135.

(12) Tributsch, H. In Sulfur; Müller, K., Krebs, B., Eds.; Studies in Inorganic Chemistry 5; Elsevier: Amsterdam, 1984; p 277.

(13) Holm, R. H. Acc. Chem. Res. 1977, 10, 427 and references cited therein.

(14) Fischer, U. In Sulfur; Müller, A., Krebs, B., Eds.; Studies in Inorganic Chemistry 5; Elsevier: Amsterdam, 1984; p 383.

(15) Vogler, A.; Kunkely, H. Inorg. Chim. Acta 1975, 14, 247.

(16) Orhanovic, M.: Sutin, N. Inorg. Chem. 1977, 16, 550.

(17) Houlding, V. H.; Mäcke, H.; Adamson, A. W. Inorg. Chem. 1981, 20 , 4279 .

(18) (a) Schwendiman, D. P.; Zink, J. I. J. Am. Chem. Soc. 1976, 98, 1248, 4439. (b) Liu, P.-H.; Zink, J. I. Ibid. 1977, 99, 2155.

(19) (a) Miessler, G. L.; Stuky, G.: Smith, T. P.: Given, K. W.: Palazotto, M. C.; Pignolet, L. H. Inorg. Chem. 1976, 15, 1982. (b) Given, K. W.; Mattson, B. M.; McGuiggan, M. F.; Miessler, G. L.; Pignolet, L. H. J. Am. Chem. Soc. 1977, 99, 4855. (c) Given, K. W.; Mattson, B. M.; Pignolet, L. H. Inorg. Chem. 1976, 15, 3152. (d) Miessler, G. L.; Zoebisch, E.; Pignolet, L. H. Ibid. 1978, 17, 3636

(20) (a) Vogler, A.; Kunkely, H. Angew. Chem., Int. Ed. Engl. 1981, 20, 368. (b) J. Am. Chem. Soc. 1981, 103, 1559. (c) Inorg. Chem. 1982, 21, 1172 .

(21) Dooley, D. M. Patterson, B. M. Inorg. Chem 1982, 21, 4330

(22) Noble, M. E. Inorg. Chem. 1987, 26,877.

(23) Bianchini, C.; Meli, A. Inorg. Chem. 1987, 26, 1345.

(24) Bernholc, J.; Stiefel, E. I. Inorg. Chem. 1985, 24, 1323 and references cited therein. istry of the isoelectronic oxyanion $\mathrm{MnO}_{4}^{-}$has been investigated in detail recently. ${ }^{27}$

Internal redox processes between an oxidizing metal such as $\mathrm{Mo}(\mathrm{VI})$ and reducing sulfide ligands seem to be a characteristic feature of the chemistry of thiometalates. ${ }^{1,28-34}$ Due to the charge-transfer (CT) nature of electronically excited states of $\left[\mathrm{MoS}_{4}\right]^{2-}$ and related complexes, ${ }^{1,24}$ such an intramolecular ligand to metal (LM) electron transfer may easily occur as a photochemical reaction. On the basis of these considerations, we started an investigation of the photochemistry of tetrasulfido complexes of oxidizing metals with a $\mathrm{d}^{0}$ electron configuration. We report here on light-induced redox reactions of $\left[\mathrm{MoS}_{4}\right]^{2-},\left[\mathrm{WS}_{4}\right]^{2-}$, $\left[\mathrm{VS}_{4}\right]^{3-}$, and $\left[\mathrm{ReS}_{4}\right]^{-}$.

\section{Experimental Section}

Materials. The compounds $\left(\mathrm{NH}_{4}\right)_{2}\left[\mathrm{MoS}_{4}\right],{ }^{35}\left[\mathrm{~N}\left(\mathrm{C}_{4} \mathrm{H}_{9}\right)_{4}\right]_{2}\left[\mathrm{MoS}_{4}\right],{ }^{24}$ $\left(\mathrm{NH}_{4}\right)_{2}\left[\mathrm{WS}_{4}\right],{ }^{36}\left(\mathrm{NH}_{4}\right)_{3}\left[\mathrm{VS}_{4}\right]$, ${ }^{37,38}$ and $\left[\mathrm{N}^{2}\left(\mathrm{CH}_{3}\right)_{4}\right]\left[\mathrm{ReS}_{4}\right]^{38,39}$ were prepared according to published procedures. Their electronic absorption spectra agreed well with those reported previously..$^{1,38-41}$ The water used in the photochemical experiments was triply distilled. Acetonitrile was Spectro Grade. Norbornadiene was purified by distillation.

Photolyses. The light sources were an Osram HBO $100 \mathrm{~W} / 2$ and a Hanovia Xe/Hg 977 B-1 (1 kW) lamp. The mercury lines at 254, 313, and $546 \mathrm{~nm}$ were selected by Schott PIL/IL interference filters. Irradiations at 214, 277, and $508 \mathrm{~nm}$ were achieved with a Schoeffel GM 250-1 monochromator. Solutions of the complexes were photolyzed in $1-\mathrm{cm}$ spectrophotometer cells at room temperature. For quantum yield determinations the complex concentrations were such as to have essentially complete light absorption. The total amount of photolysis was limited to less than $5 \%$ to avoid light absorption by the photoproducts. Absorbed light intensities were determined by a Polytec pyroelectric radiometer that was calibrated and equipped with an $\mathrm{RkP}-345$ detector.

Progress of the photolysis was monitored by UV-visible spectral measurements with a Uvikon 810 recording spectrophotometer and a

(25) Clark, R. J. H.; Dines, T. J.; Wolf, M. L. J. Chem. Soc., Faraday Trans. 2 1982, 78,679

(26) Clark, R. J. H.; Dines, T. J.; Proud, G. P. J. Chem. Soc., Dalton Trans. $1983,2019$.

(27) Lee, D. G.; Moylan, C. R.; Hayashi, T.; Brauman, J. I. J. Am. Chem. Soc. 1987, 109, 3003.

(28) Rittner, W.; Müller, A.; Neumann, A.; Bäther, W.; Sharma, R. C. Angew. Chem., Int. Ed. Engl. 1979, 18, 530.

(29) Draganjac, M.; Simhon, E.; Chan, L. T.; Kanatzidis, M.; Baenziger, N. C.: Coucouvanis, D. Inorg. Chem. 1982, 21, 3321.

(30) Pan, W.-H.: Harmer, M. A.; Halbert, T. R.; Stiefel, E. I. J. Am. Chem. Soc. 1984, 106, 459 .

(31) Pan, W.-H.; Halbert, T. R.; Hutchings, L. L.; Stiefel, E. I. J. Chem. Soc., Chem. Commun. 1985, 927.

(32) Xin, X.; Morris, N. L.; Jameson, G. B.; Pope, M. T. Inorg. Chem. 1985 24,3482 .

(33) Cohen, S. A.; Stiefel, E. I. Inorg. Chem. 1985, 24, 4657

(34) Müller, A.; Römer, M.; Römer, C.; Reinsch-Vogell, U.; Bögge, H.; Schimanski, U. Monatsh. Chem. 1985, 116, 711 .

(35) Krüss, G. Liebigs Ann. Chem. 1884, 225, 1 .

(36) Corleis, E. Liebigs Ann. Chem. 1886, 232, 244

(37) (a) Krüss, G.; Ohnmais, K. Chem, Ber. 1890, 23, 2547. (b) Liebigs Ann. Chem. 1891, 263, 39 .

(38) Do, Y : Simhon, E D. Holm, R. H. Inorg. Chem 1985, 24, 4635

(39) Müller, A.; Diemann, E.; Rao, V. V. K. Chem. Ber. 1970, 103, 2961.

(40) Müller, A.; Diemann, E. Chem. Phys. Lett. 1971, $9,369$.

(41) Müller, A.; Krebs, B.; Rittner, W.; Stockburger, M. Ber. Bunsen-Ges. Phys. Chem. 1967, 71, 182. 


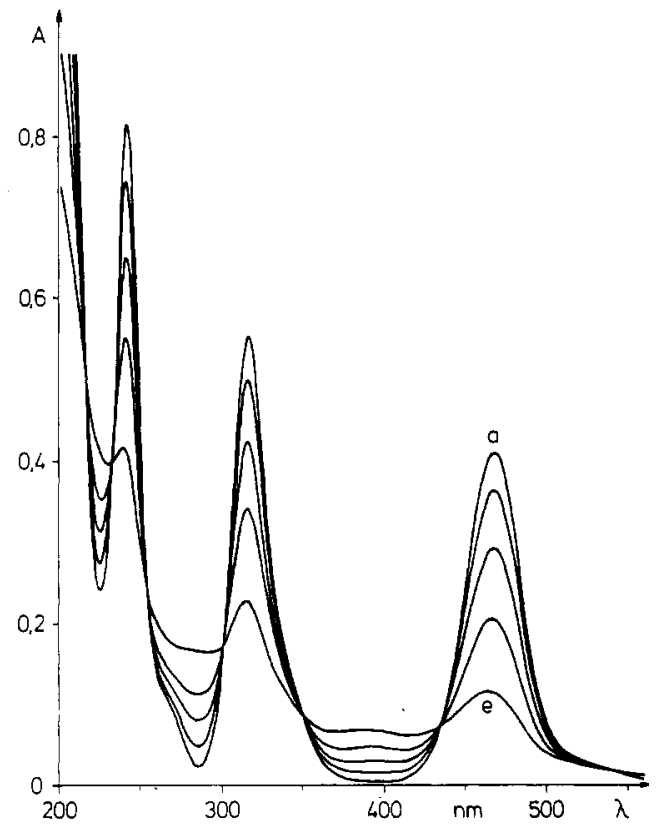

Figure 1. Spectral changes during the photolysis of aqueous $2.95 \times 10^{-5}$ $\mathrm{M}\left(\mathrm{NH}_{4}\right)_{2}\left[\mathrm{MoS}_{4}\right]$ at (a) 0 and (e) 20-min irradiation time, with $\lambda_{\text {irr }}>$ $200 \mathrm{~nm}$ and a $1-\mathrm{cm}$ cell.

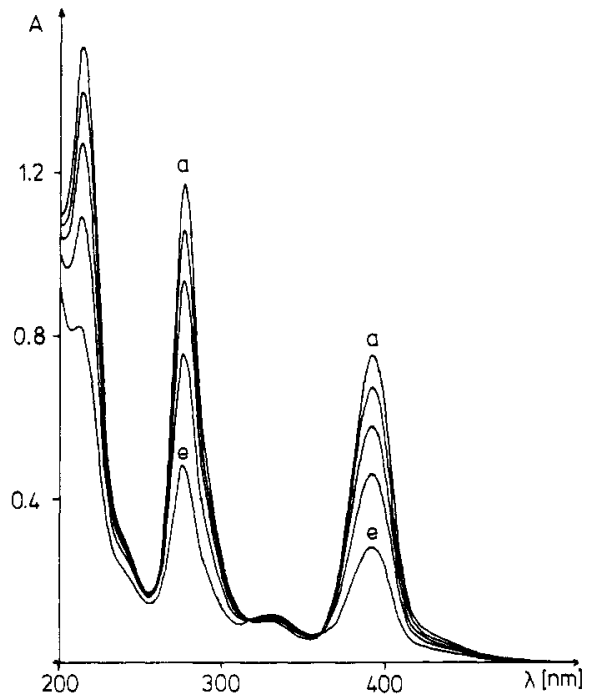

Figure 2. Spectral changes during the photolysis of aqueous $4.06 \times 10^{-5}$ $\mathrm{M}\left(\mathrm{NH}_{4}\right)_{2}\left[\mathrm{WS}_{4}\right]$ at (a) 0 and (e) 75-min irradiation time, with $\lambda_{\text {irr }}>200$ $\mathrm{nm}$ and a $1-\mathrm{cm}$ cell.

Zeiss PMQ II spectrometer for measurements at selected wavelengths. The photoproducts $\left[\mathrm{MoO}_{2} \mathrm{~S}_{2}\right]^{2-, 41,42}\left[\mathrm{WO}_{2} \mathrm{~S}_{2}\right]^{2-41,42}$ and $\left[\mathrm{VO}_{2} \mathrm{~S}_{2}\right]^{3-43}$ were identified by their absorption spectra. As indicated by the spectral changes (Figures 1-3), the photolyses took place without side reactions. At the isosbestic points the starting complexes $\left[\mathrm{MS}_{4}\right]^{n-}$ and the photoproducts $\left[\mathrm{MO}_{2} \mathrm{~S}_{2}\right]^{n-}$ have the same extinction coefficients: $\mathrm{M}=\mathrm{Mo}, \lambda$ $=255 \mathrm{~nm}(\epsilon=7650), \lambda=301 \mathrm{~nm}(\epsilon=5760), \lambda=350 \mathrm{~nm}(\epsilon=2800)$, $\lambda=434 \mathrm{~nm}(\epsilon=2400) ; M=W, \lambda=316 \mathrm{~nm}(\epsilon=2770), \lambda=360 \mathrm{~nm}$ $(\epsilon=1600) ; \mathrm{M}=\mathrm{V}, \lambda=442 \mathrm{~nm}(\epsilon=1090), \lambda=492 \mathrm{~nm}(\epsilon=1130)$.

The decrease of concentration of $\left[\mathrm{MS}_{4}\right]^{n}$ during the photolysis was determined by measuring the extinction at the absorption maximum: $M$ $=\mathrm{Mo}, \lambda_{\max }=468 \mathrm{~nm}(\epsilon=13800) ; \mathrm{M}=\mathrm{W}, \lambda_{\max }=392 \mathrm{~nm}(\epsilon=18600)$; $M=V, \lambda_{\max }=545 \mathrm{~nm}(\epsilon=5810)$. At these wavelengths the residual absorption by the photoproduct $\left[\mathrm{MO}_{2} \mathrm{~S}_{2}\right]^{n-}$ was neglected. The experimental error of the quantum yield determinations was $\pm 5 \%$.

The isolation of $\left[\mathrm{ReO}_{2} \mathrm{~S}_{2}\right]^{-}$was not described in the literature. The reported absorption maxima at $\lambda=400$ and $312 \mathrm{~nm}$ were tentative

(42) Müller, A.; Diemann, E.; Ranade, A. C.; Aymonino, P. J. Z. Naturforsch., B: Anorg. Chem., Org. Chem., Biochem., Biophys., Biol. 1969, $24 B, 1247$.

(43) Ranade, A. C.; Müller, A.; Diemann, E. Z. Anorg. Allg. Chem. 1970 $373,258$.

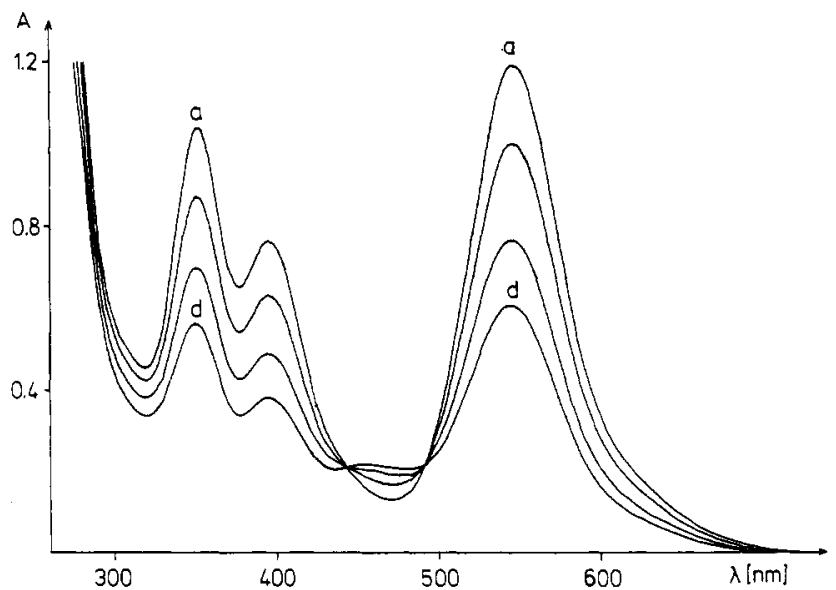

Figure 3. Spectral changes during the photolysis of $2.04 \times 10^{-4} \mathrm{M}$ $\left(\mathrm{NH}_{4}\right)_{3}\left[\mathrm{VS}_{4}\right]$ in $1 \mathrm{M} \mathrm{NaOH}$ at (a) 0 and (d) 8-min irradiation time, with $\lambda_{\text {irr }}>490 \mathrm{~nm}$ and a $1-\mathrm{cm}$ cell.

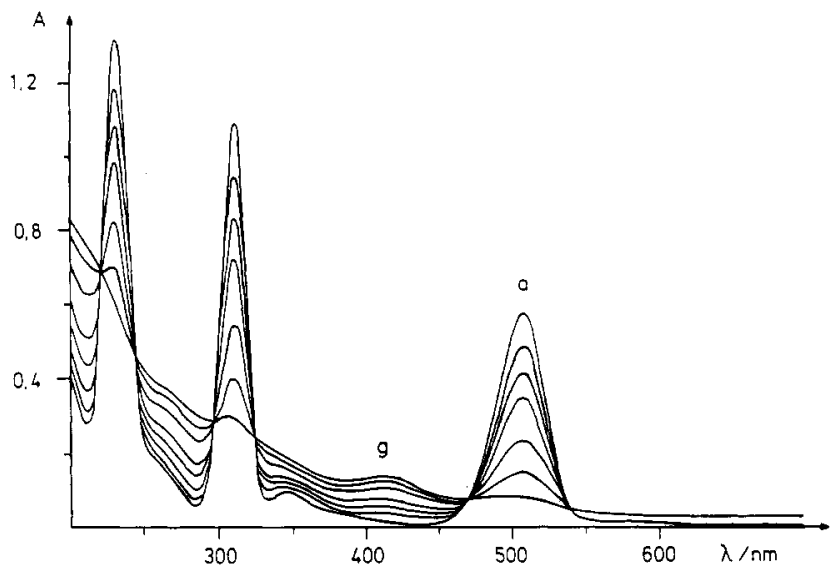

Figure 4. Spectral changes during the photolysis of $5.96 \times 10^{-5} \mathrm{M}$ $\left[\mathrm{N}\left(\mathrm{CH}_{3}\right)_{4}\right]\left[\mathrm{ReS}_{4}\right]$ in acetonitrile at (a) 0 and (g) 70 -min irradiation time, with $\lambda_{\text {irr }}=460-560 \mathrm{~nm}$ and a $1-\mathrm{cm}$ cell.

observations. ${ }^{1,43}$ Nevertheless, $\left[\mathrm{ReO}_{2} \mathrm{~S}_{2}\right]^{-}$was assumed to be the photoproduct of $\left[\operatorname{ReS}_{4}\right]^{-}$since the spectral changes that occur during the photolysis of all four complexes are rather similar. Some deviations are explained below. The decrease of concentration of $\left[\mathrm{ReS}_{4}\right]^{-}$during the photolysis was determined by measuring the extinction at its absorption maximum $\lambda_{\max }=508 \mathrm{~nm}(\epsilon=9700)$. At this wavelength the small absorption of the photoproduct (Figure 4) was neglected.

Elemental sulfur as other photoproduct was separated by centrifuging and dissolved in $\mathrm{CHCl}_{3}$. It was determined by its extinction at $\lambda=300$ $\mathrm{nm}(\epsilon=2940){ }^{44}$ As an example, an aqueous solution $(100 \mathrm{~mL})$ of 3.3 $\times 10^{-3} \mathrm{M}\left(\mathrm{NH}_{4}\right)_{2}\left[\mathrm{MoS}_{4}\right]$ was photolyzed with light of $\lambda=254 \mathrm{~nm}$ in the presence of oxygen. After 20 -min irradiation time $1.17 \times 10^{-4} \mathrm{M}$ $\left[\mathrm{MoS}_{4}\right]^{2-}$ was converted to $\left[\mathrm{MoO}_{2} \mathrm{~S}_{2}\right]^{2-}$, as determined by spectrophotometric analysis. The sulfur was dissolved in $\mathrm{CHCl}_{3}(100 \mathrm{~mL})$. The concentration of sulfur was $0.24 \times 10^{-4} \mathrm{M}$. This is $18 \%$ less than expected according to the proposed stoichiometry (see below).

\section{Results}

In the presence of air the irradiation of diluted $\left(\sim 10^{-5}\right)$ aqueous solutions of $\left[\mathrm{MoS}_{4}\right]^{2-}$ with white light was accompanied by spectral changes (Figure 1) that clearly indicated the formation of $\left[\mathrm{MoO}_{2} \mathrm{~S}_{2}\right]^{2-41,42}$ The final spectrum (Figure 1) corresponds to $80 \%$ conversion of $\left[\mathrm{MoS}_{4}\right]^{2-}$ to $\left[\mathrm{MoO}_{2} \mathrm{~S}_{2}\right]^{2-}$. In solutions that were deaerated by saturation with argon, $\left[\mathrm{MoS}_{4}\right]^{2-}$ was essentially not light-sensitive. However, a very slow and incomplete photolysis took place with the same spectral variations as those that were observed in the presence of air. It was assumed that the photolysis in deaerated solutions was caused by trace amounts of oxygen,

(44) The spectrophotometric analysis of elemental sulfur was described previously. ${ }^{45}$ However, the extinction coefficient at $300 \mathrm{~nm}$ was different from that of the present work.

(45) LaMer, V. K.; Kenyon, A. S. J. Colloid Sci. 1947, 2, 257. 
which are difficult to remove. In the presence of oxygen the formation of $\left[\mathrm{MoO}_{2} \mathrm{~S}_{2}\right]^{2-}$ was accompanied by the release of elemental sulfur:

$$
\left[\mathrm{MoS}_{4}\right]^{2-}+\mathrm{O}_{2} \rightarrow\left[\mathrm{MoO}_{2} \mathrm{~S}_{2}\right]^{2-}+{ }^{1} / \mathrm{S}_{8}
$$

At low complex concentrations $\left(\sim 10^{-5} \mathrm{M}\right)$ the formation of elemental sulfur could not be detected. But at higher concentrations $\left(>10^{-3} \mathrm{M}\right)$ sulfur formed a colloid, which led to light scattering over the entire absorption spectrum. At complex concentrations of $\sim 10^{-2} \mathrm{M}$ the elemental sulfur precipitated. It was separated by centrifuging and determined spectrophotometrically. This analysis agreed fairly well with the stoichiometry of the equation as proposed above. At $\lambda_{\text {irr }}=254 \mathrm{~nm}$ the quantum yield of this photoreaction was $\Phi=0.15$. It dropped to $\Phi<10^{-3}$ for $\lambda_{\mathrm{irr}}>300 \mathrm{~nm}$. In alkaline solution the efficiency of the photolysis did not depend on the $\mathrm{pH}$.

It was assumed that sulfur was initially released as $S_{2}$, which finally yields stable $S_{8}$. Diatomic sulfur is known to undergo efficient Diels-Alder trapping by certain olefins such as norbornadiene ${ }^{46,47}$ The photolysis $\left(\lambda_{\text {irr }}=313 \mathrm{~nm}\right)$ of $10^{-2} \mathrm{M}[\mathrm{N}$ $\left.\left(\mathrm{C}_{4} \mathrm{H}_{9}\right)_{4}\right]_{2}\left[\mathrm{MoS}_{4}\right]$ in acetonitrile was carried out in the presence of $2 \times 10^{-2} \mathrm{M}$ norbornadiene. The olefin does not absorb at this wavelength. After an irradiation time of $5 \mathrm{~h}$, the starting complex and the photoproduct $\left[\mathrm{N}\left(\mathrm{C}_{4} \mathrm{H}_{9}\right)_{4}\right]_{2}\left[\mathrm{MoO}_{2} \mathrm{~S}_{2}\right]$ were separated by the addition of ether. The filtered solution was evaporated at room temperature. The residue was analyzed by mass spectroscopy. The presence of the mass 188 clearly indicated the formation of the trisulfide $\mathrm{C}_{7} \mathrm{H}_{8} \mathrm{~S}_{3}$ by the reaction of norbornadiene with diatomic sulfur. ${ }^{47}$

The irradiation of aqueous solutions of $\left[\mathrm{WS}_{4}\right]^{2-}$ led to results that were very similar to those obtained for $\left[\mathrm{MoS}_{4}\right]^{2-}$. In the presence of air the photolysis of $\left[\mathrm{WS}_{4}\right]^{2-}$ was accompanied by spectral changes (Figure 2) that indicated clearly the formation of $\left[\mathrm{WO}_{2} \mathrm{~S}_{2}\right]^{2-41,42}$ At higher complex concentrations $\left(>10^{-3} \mathrm{M}\right)$ the photochemical formation of elemental sulfur was detected. The photolysis proceeds apparently by the same stoichiometry as that of $\left[\mathrm{MoS}_{4}\right]^{2-}$. At $\lambda_{\text {irr }}=214 \mathrm{~nm}$ the quantum yield was $\Phi=$ 0.038 . It dropped to $\Phi=4 \times 10^{-3}$ at $\lambda_{\text {irr }}=277 \mathrm{~nm}$.

The photolysis of $\left[\mathrm{VS}_{4}\right]^{3-}$ was carried out in alkaline $(1 \mathrm{M}$ $\mathrm{NaOH}$ ) solution since this complex is not stable in neutral solution. The spectral changes (Figure 3 ) are in agreement with the formation of $\left[\mathrm{VO}_{2} \mathrm{~S}_{2}\right]^{3-} \cdot{ }^{43}$ The photolysis that proceeds only in the presence of oxygen was accompanied by the formation of sulfur. In contrast to the corresponding molybdenum and tungsten complexes, $\left[\mathrm{VS}_{4}\right]^{3-}$ was quite light-sensitive upon irradiation of its long-wavelength band. $\left[\mathrm{VO}_{2} \mathrm{~S}_{2}\right]^{3-}$ was formed with a quantum yield $\Phi=0.14$ at $\lambda_{\text {irr }}=546 \mathrm{~nm}$.

Since $\left[\mathrm{ReS}_{4}\right]^{-}$can be isolated only as the tetraalkylammonium or phosphonium salt, both of which are insoluble in water, the photolysis was carried out in acetonitrile. The spectral changes that accompanied the photoreaction in the presence of air (Figure 4) are qualitatively similar to those of the other tetrasulfido complexes. It was assumed that $\left[\mathrm{ReO}_{2} \mathrm{~S}_{2}\right]^{-1,43}$ was formed. However, in acetonitrile the formation of colloidal sulfur occurred already at very low concentrations. The spectral variations (Figure 4) include an apparent extinction due to light scattering by the colloidal sulfur. This extinction increases with decreasing wavelength. In analogy to $\left[\mathrm{VS}_{4}\right]^{3-}$ the light sensitivity of $\left[\mathrm{ReS}_{4}\right]^{-}$ extends to the long-wavelength band. $\left[\mathrm{ReS}_{4}\right]^{-}$disappeared with a quantum yield of $\Phi=0.14$ at $\lambda_{\text {irr }}=313 \mathrm{~nm}$ and $\Phi=0.08$ at $\lambda_{\text {irr }}=508 \mathrm{~nm}$.

\section{Discussion}

Electronic Spectra. All four complexes $\left[\mathrm{MS}_{4}\right]^{n-}$ with $\mathbf{M}=$ Mo(VI), W(VI), V(V), and $\operatorname{Re}(\mathrm{VII})$ are tetrahedral ${ }^{1}$ and contain the metal with a $d^{0}$ electron configuration. At low energies all electronic transitions are then LMCT transitions from the sulfide

(46) Steliou, K.; Gareau, Y.; Harpp, D. N. J. Am. Chem. Soc, 1984, 106, 799.

(47) Steliou, K.; Salama, P.; Brodeur, D; Gareau, Y. J. Am. Chem. Soc. 1987, 109,926 . ligands to the metal. ${ }^{1}$ However, at these high formal oxidation states of the metal, the bonding in these complexes must have large covalent contributions. It follows that some of the MO's are strongly delocalized between metal and ligands. LMCT transitions may then not be associated with the transfer of much charge from the ligand to the metal.

The absorption spectra of the four $\left[\mathrm{MS}_{4}\right]^{n-}$ complexes are rather similar (Figures 1-4). Since the electronic structure of $\left[\mathrm{MoS}_{4}\right]^{2-}$ has been investigated in detail, $1,24,40,48$ only the spectrum of this complex will be discussed here. Appropriate assignments of absorption bands of the other complexes are then quite obvious. The red shift of the LMCT absorption bands from W(VI) to Mo(VI), $\operatorname{Re}(V I I)$, and $V(V)$ (Figure $1-4$ ) reflects certainly the increasing oxidation strength in this series. In comparison to those of the corresponding oxyanions $\mathrm{MO}_{4}{ }^{n}$, the absorption bands of $\mathrm{MS}_{4}{ }^{n-}$ are shifted to longer wavelength since sulfide is a stronger reductant than oxide.

The MO's of $\left[\mathrm{MoS}_{4}\right]^{n-}$ that are involved in electronic transitions above $200 \mathrm{~nm}$ are the filled $3 \mathrm{t}_{2}$ and $1 \mathrm{t}_{1}$ (HOMO) and the empty $2 \mathrm{e}^{*}$ (LUMO) and $4 \mathrm{t}_{2}{ }^{*}$ orbitals. $1,24,40$ The $1 \mathrm{t}_{1}$ level is a pure sulfur orbital that is slightly antibonding with respect to the sulfur-sulfur interaction. ${ }^{24}$ The $3 \mathrm{t}_{2}$ level is largely composed of sulfur orbitals $(\sim 90 \%)$ with a minor contribution by the metal $(\sim 10 \%)$. This $3 \mathrm{t}_{2}$ orbital is weakly $S-S$ bonding. The empty MO's $2 \mathrm{e}^{*}$ and $4 \mathrm{t}_{2}{ }^{*}$, which are antibonding with respect to metal-ligand interaction, are composed of comparable portions of metal and ligand orbitals. It follows that all electronic transitions are of the LMCT type and are associated with the transfer of a considerable fraction of charge from the ligand to the metal. While there is a general agreement that the longest wavelength band of $\left[\mathrm{MoS}_{4}\right]^{2-}$ at $\lambda_{\max }$ $=468 \mathrm{~nm}(\epsilon=13800)$ is assigned to the $1 \mathrm{t}_{1} \rightarrow 2 \mathrm{e}^{*}$ transition the ordering of the higher energy transitions $\left(3 \mathrm{t}_{2} \rightarrow 2 \mathrm{e}^{*}, 1 \mathrm{t}_{1} \rightarrow 4 \mathrm{t}_{2}{ }^{*}\right.$, $\left.3 \mathrm{t}_{2} \rightarrow 4 \mathrm{t}_{2}{ }^{*}\right)$ is not quite clear. By resonance Raman spectroscopy of $\left[\mathrm{MoS}_{4}\right]^{2-}$ and $\left[\mathrm{WS}_{4}\right]^{2-}$, it was shown that LMCT excitation $\left(1 \mathrm{t}_{1} \rightarrow 2 \mathrm{e}^{*}\right)$ leads indeed to a $\mathrm{M}-\mathrm{S}$ bond extension of 0.058 and $0.07 \AA$, respectively. This is not as large as that of $\mathrm{MnO}_{4}^{-}(0.09$ A).

Photochemistry. The photochemistry of all four $\left[\mathrm{MS}_{4}\right]^{n-}$ complexes can be described by the following scheme $(*=$ LMCT state):

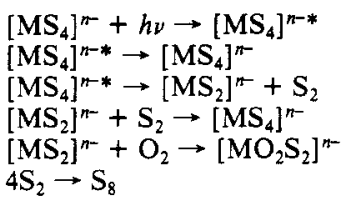

light absorption radiationless deactivation reductive elimination recombination oxidative addition

The LMCT state of $\left[\mathrm{MS}_{4}\right]^{n-}$ undergoes apparently a reductive elimination of $S_{2}$. It is rather interesting that the same mechanism has been recently proposed for the photolysis of the isoelectronic complex $\left[\mathrm{MnO}_{4}\right]^{-27}$ In the absence of oxygen the $\left[\mathrm{MS}_{2}\right]^{n-}$ fragment oxidatively adds the released $\mathrm{S}_{2}$ and regenerates $\left[\mathrm{MS}_{4}\right]^{n-}$. In the presence of air $\mathrm{S}_{2}$ and $\mathrm{O}_{2}$ compete in the oxidative addition. The reaction with oxygen yields the stable photoproduct $\left[\mathrm{MO}_{2} \mathrm{~S}_{2}\right]^{n-}$. Diatomic sulfur as intermediate can be scavenged by norbornadiene to yield a Diels-Alder addition product.

While the proposed mechanism of the photolysis of $\left[\mathrm{MS}_{4}\right]^{n-}$ is certainly reasonable, the origin for the dependence of the quantum yield on the irradiating wavelength is not quite clear. The quantum yield increases with decreasing wavelength. This could be an indication that, regardless of the type of LMCT state, shorter wavelength irradiation provides an excess of kinetic energy for the ejection of $S_{2}$. This could favor the reductive elimination in competition with the radiationless deactivation. Another surprising feature is the observation that $\left[\mathrm{VS}_{4}\right]^{3-}$ and $\left[\mathrm{ReS}_{4}\right]^{-}$are quite light-sensitive upon $1 \mathrm{t}_{1} \rightarrow 2 \mathrm{e}^{*}$ LMCT excitation by light absorption into the longest wavelength band while $\left[\mathrm{MoS}_{4}\right]^{2-}$ and $\left[\mathrm{WS}_{4}\right]^{2-}$ require irradiation of the shorter wavelength $\mathrm{LMCT}$ absorptions. In this context, it is interesting that the $1 t_{1} \rightarrow 2 e^{*}$

(48) Liang, K. S.; Bernholc, J.; Pan, W.-H.; Hughes, G. J.; Stiefel, E. I. Inorg. Chem. 1987, 26, 1422. 
LMCT state of $\left[\mathrm{MoS}_{4}\right]^{2-}$ and $\left[\mathrm{WS}_{4}\right]^{2-}$ is not much distorted with regard to the ground state while $\left[\mathrm{MnO}_{4}\right]^{-}$, which photolyses efficiently upon long-wavelength irradiation, ${ }^{27}$ is distorted much more strongly. ${ }^{25,26}$ Unfortunately, the excited-state distortions of $\left[\mathrm{VS}_{4}\right]^{3-}$ and $\left[\mathrm{ReS}_{4}\right]^{-}$are not known to establish a correlation between the extent of excited state distortion and the efficiency of the photoreaction.
Acknowledgment. Financial support for this research by the Deutsche Forschungsgemeinschaft and the Fonds der Chemischen Industrie is gratefully acknowledged.

Registry No. $\left[\mathrm{MoS}_{4}\right]^{2-}, 16330-92-0 ;\left[\mathrm{WS}_{4}\right]^{2-}, 14916-78-0 ;\left[\mathrm{VS}_{4}\right]^{3-}$, 14791-51-6; [ReS $]_{4}^{-}, 16829-47-3 ;\left[\mathrm{MoO}_{2} \mathrm{~S}_{2}\right]^{2-}, 16608-22-3$; $\left[\mathrm{WO}_{2} \mathrm{~S}_{2}\right]^{2-}$, 16450-49-0; $\left[\mathrm{VO}_{2} \mathrm{~S}_{2}\right]^{3-}, 26815-91-8 ;\left[\mathrm{ReO}_{2} \mathrm{~S}_{2}\right]^{-}, 112113-55-0 ; \mathrm{O}_{2}, 7782-$ $44-7 ; S_{2}, 23550-45-0 ; S_{8}, 10544-50-0$.

Contribution from the Department of Chemistry

and the Molecular Structure Center, Indiana University, Bloomington, Indiana 47405

\title{
Metal/Sulfide/Thiolate Chemistry for an Early 3d Transition Metal: Variation of Product Identity as a Function of V:S Reaction Ratio and Structure and Redox Properties of Discrete V/S/edt Complexes
}

\author{
Joanna K. Money, John C. Huffman, and George Christou* ${ }^{\dagger}$ \\ Received April 21, 1987
}

\begin{abstract}
A systematic investigation of the $\mathrm{VCl}_{3} /$ elemental $\mathrm{S} / \mathrm{Na}_{2}$ edt reaction system in $\mathrm{MeCN}$ is described. Particular emphasis has been placed on determining the influence of the $\mathrm{S}: \mathrm{V}$ ratio $(n)$ on the identity of the reaction product(s). Values of $n$ in the 0-2.5 range have been employed. In some cases, the influence of the $\operatorname{edt}^{2-}: \mathrm{V}$ ratio on reaction product(s) has also been investigated. These combined variations have led to the synthesis of five discrete complexes, the structures of two of which are described. The $n=$ 0 reaction ratio leads to high-yield preparation of $\left(\mathrm{PPh}_{4}\right)_{2}\left[\mathrm{~V}_{2}(\mathrm{edt})_{4}\right](\mathbf{1})$. The $n=0.5$ reaction ratio yields a mixture of products, being composed of an approximately 3:1 ratio of $\left(\mathrm{NEt}_{4}\right)_{2}\left[\mathrm{~V}_{2}(\mathrm{edt})_{4}\right]$ and $\left(\mathrm{NEt}_{4}\right)_{3}\left[\mathrm{~V}_{3} \mathrm{~S}_{4}(\mathrm{edt})_{3}\right]$ (2). Complex 2 crystallizes in the monoclinic space group $P 2_{1} / n$ with the following unit cell dimensions at $-154^{\circ} \mathrm{C}: a=14.168(5) \AA, b=18.446(7) \AA, c=19.803$ (8) $\AA, \beta=104.91(2)^{\circ}$, and $Z=4$. A total of 3806 unique reflections with $F>2.33 \sigma(F)$ were employed, and the structure solution was refined to values of conventional indices $R$ and $R_{\mathrm{w}}$ of 8.39 and $8.59 \%$, respectively. The structure of the anion of 2 consists of a $V_{3}$ triangle with one central capping $\mu_{3}-\mathrm{S}$ atom and a $\mu-\mathrm{S}$ atom bridging each edge. A terminal edt completes five-coordination at each metal. The $\mathrm{V}_{3} \mathrm{~S}_{4}$ core can be described as a "partial cube" and is isostructural with the more common $\mathrm{Mo}_{3} \mathrm{~S}_{4}$ cores in $\mathrm{Mo} / \mathrm{S}$ chemistry. Charge considerations necessitate a mixed-valence trivanadium(III,2IV) description, but on the basis of inspection of structural parameters, there is no justification for a trapped-valence assignment, and the anion is best described as electronically delocalized with an average metal oxidation state of $+3^{2} / 3$. The $n=1$ reaction ratio yields $\left(\mathrm{NEt}_{4}\right) \mathrm{Na}$ [VS(edt) ${ }_{2}$ (3), the structure of which had been determined in previous work and contains the multiply bonded VS ${ }^{2+}$ unit. The $n=1.5$ reaction ratio gave differing products depending on the edt ${ }^{2-}: \mathrm{V}$ ratio employed. When $\operatorname{edt}^{2-}: \mathrm{V}=3: 1$, high yields of 3 were obtained, whereas an edt ${ }^{2-}: \mathrm{V}$ $=2: 1$ ratio yielded a preparative route to pure 2 . This difference in behavior is attributed to the strongly chelating nature of the edt $^{2-}$ ligand favoring complex 3 when sufficient edt $^{2-}$ is available and preventing aggregation by further incorporation of available $\mathrm{S}^{2-}$. The $n=2$ ratio also yielded differing products, depending on the edt ${ }^{2-}: \mathrm{V}$ ratio. When this ratio was $5: 1$, the product again was 3. When this ratio was $2.5: 1$, a mixture of highly crystalline $\left(\mathrm{NEt}_{4}\right)_{2} \mathrm{Na}\left[\mathrm{V}_{2} \mathrm{OS}_{4}(\mathrm{edt})\right]$ (4) and microcrystalline $\left(\mathrm{NEt}_{4}\right)_{2} \mathrm{Na}$ $\left[\mathrm{V}_{2} \mathrm{~S}_{5}(\mathrm{edt})\right]$ (5) was obtained; the two materials have been satisfactorily separated manually. Complex 4 crystallizes in the monoclinic space group $P 2 / c$ with the following unit cell dimensions at $-155^{\circ} \mathrm{C}: a=12.955(6) \AA, b=15.963(8) \AA, c=15.338$ (8) $\AA, \beta=109.83(2)^{\circ}$, and $Z=4$. A total of 3112 unique reflections with $F>3.00 \sigma(F)$ were employed, and the structure solution was refined to values of conventional indices $R$ and $R_{\mathrm{w}}$ of 4.34 and $4.37 \%$, respectively. The anion of 4 consists of a five-coordinate vanadium(IV) atom bridged by two $\mu-S^{2-}$ species to a four-coordinate vanadium(V) atom. The former additionally contains terminal edt ${ }^{2-}$ and $\mathrm{O}^{2-}$ groups, while the latter contains two terminal $\mathrm{S}^{2-}$ groups. Complex $\mathbf{5}$ is assigned the same structure but with $\mathrm{O}^{2-}$ replaced by $\mathrm{S}^{2-}$. The $n=2.5$ reaction ratio was found to yield only complex 5 . The cyclic voltammetric properties of these complexes are also described, and the isolated oxidation levels are shown to be members of multicomponent electron-transfer series, with the exception of 3 , which shows no reversible behavior.
\end{abstract}

\section{Introduction}

It is becoming increasingly apparent that the chemistry of vanadium bound to sulfur is of great relevance and/or importance to a wide variety of chemical, industrial, and biological systems. For example, the polymeric group 5 sulfides have exhibited interesting magnetic and electrical properties, and substances such as $\mathrm{Li}_{x} \mathrm{VS}_{2}$ (and the group 4 sulfide $\mathrm{Li}_{x} \mathrm{TiS}_{2}$ ) have been attracting the attention of industrial researchers seeking novel conducting materials for use as electrodes in solid-state batteries. ${ }^{1}$ In addition, the large amounts of vanadium impurities in the heavier crude oils result in conversion of the former to insoluble vanadium sulfide deposits, which help to poison the Mo/Co catalyst during hydrodesulfurization (HDS). This has stimulated interest in both the identity of the crude oil impurities and the mechanism of their subsequent conversion to vanadium sulfide. ${ }^{2}$ Finally, the recent identification of a vanadium nitrogenase ${ }^{3}$ its subsequent study by the EXAFS technique, ${ }^{4}$ and comparison with the better understood Mo nitrogenase suggest that the vanadium is located in

${ }^{\dagger}$ Alfred P. Sloan Research Fellow, 1987-1989 and Camille and Henry Dreyfus Teacher-Scholar, 1987-1992. a complete or partial environment of sulfur.

The combined developments described above have suggested to us that the time had come for a better understanding of the fundamental chemistry and properties of discrete complexes containing vanadium bound to sulfide and/or sulfur-based ligands such as thiolate $\left(\mathrm{RS}^{-}\right)$. This belief represents the primary stimulus for the work described herein. In addition, such studies with a 3d metal would provide illuminating comparisons and contrasts with $4 \mathrm{~d} \mathrm{Mo} / \mathrm{S}$ and $5 \mathrm{~d} \mathrm{~W} / \mathrm{S}$ chemistry, both of which have already been extensively developed. ${ }^{5}$

(1) (a) Hullinger, F. Struct. Bonding (Berlin) 1968, 4, 83. Rouxel, J.; Brec, R. Annu. Rev. Mater. Sci. 1986, 16, 137. (b) Murphy, D. W.; Christian, P. A. Science (Washington, D.C.) 1979, 205, 651.

(2) (a) Rankel, L. A.; Rollman, L. D. Fuel 1983, 62, 44. (b) Galiasso, R.; Blanco, R.; Gonzalez, C.; Quinteros, N. Fuel 1983, 62, 817. (c) Silbernagel, B. G. J. Catal. 1979, 56, 315. (d) Reynolds, J. G.; Biggs, W. R.; Fetzer, J. C. Liq. Fuels Technol. 1985, 3, 423.

(3) (a) Robson, R. L.; Eady, R. R.; Richardson, T. H.; Miller, R. W.; Hawkins, M.; Postgate, J. R. Nature (London) 1986, 322, 388. (b) Hales, B. J.; Case, E. E.; Morningstar, J. E.; Dzeda, M. F.; Mauterer, L. A. Biochemistry 1986, 25, 7251 .

(4) Arber, J. M.; Dobson, B. R.; Eady, R. R.; Stevens, P.; Hasnain, S. S.; Garner, C. D.; Smith, B. E. Nature (London) 1987, 325, 372. 